\title{
Life cycle inventory for currently harvested birch roundwood
}

\author{
Edgars Kuka $^{1,2 *}$, Dace Cirule ${ }^{1}$, Ingeborga Andersone ${ }^{1}$, and Bruno Andersons ${ }^{1}$ \\ ${ }^{1}$ Laboratory of Wood Biodegradation and Protection \\ Latvian State Institute of Wood Chemistry \\ Riga, LV-1006, Latvia \\ ${ }^{2}$ Faculty of Material Science and Applied Chemistry \\ Riga Technical University \\ Riga, LV-1048, Latvia
}

\begin{abstract}
The knowledge of the environmental performance of different products and services is vital in the modern world because of the climate change and other environmental problems that we are facing. Life cycle assessment is a valuable tool that allows to determine the environmental performance and compare products and services with the same function. There is no doubt that the importance of forests is crucial in the environmental protection, despite that raw wood products (roundwood, pulpwood and fuelwood) are not carbon neutral as previously thought because of the human activities during forest management processes. Apart from climate change, production of raw wood products also contribute to other environmental impact categories: acidification, eutrophication, photochemical oxidant formation and abiotic resource depletion. Previous studies have shown that the life cycle inventory (LCI) data for raw wood products should be collected from the site-specific not from more generic sources because of the significant differences in several geography and technology related factors. However, less discussed are time-related factors, which should also be acknowledged especially because of the long growing time of trees.

The main objective of the present study was to determine which forest management processes should be included in the LCI for currently harvested birch (Betula spp.) roundwood in Latvia and based on these results compile the required data for the LCI. The results of forest management history analysis showed that for currently produced birch roundwood only logging operations should be included in the system boundary. Subsystems such as seed production, seedling production and silvicultural operations were not practiced or had only minor impact due to low mechanization level in the past. By taking into account the time-related factors, the LCI was developed and can be used in further calculations of environmental impacts for different wood-based products that are manufactured from currently harvested birch roundwood.
\end{abstract}

\section{INTRODUCTION}

Forest products are low emission raw materials and not carbon neutral as previously thought. The roundwood production/harvesting process can emit 2 to $60 \mathrm{~kg} \mathrm{CO}_{2}$-equiv. per $\mathrm{m}^{3}$ depending on wood species, geographical region, forest management practices, used technology, system boundary and assumptions of the life cycle assessment (LCA) study etc. (Klein et al. 2015, Cardellini 2018). These emissions contribute to climate change, which is the main concern nowadays. Besides that, the production of the forest products contribute also to other environmental impact categories: acidification, eutrophication, photochemical oxidant formation and abiotic resource depletion (Dias and Arroja 2012). LCA is the most accepted methodology that allows to quantify these environmental impacts for a specific product or service. The standardized methodology involves an extensive collection of relevant data and calculation of environmental impacts expressed as indicators for specific environmental impact category. The most critical and time consuming is the data collection or life cycle inventory (LCI) stage. The LCI gives a quantitative information about the inputs and outputs of the unit processes that concern the product system under study. The results and main conclusions of such studies are highly affected by the quality of the collected data. It has been pointed out that the LCI data for forest products should be taken from the site-specific not from more generic sources because of the major differences in several geography and technology related factors (Bosner et al. 2012, Gonzalez-Garcia et al. 2013, Klein et al. 2015, Cardellini 2018). Less discussed are time-related factors which should also be acknowledged especially because of the long growing time of trees. Most of the studies assume that roundwood is produced by using the current forest management practices and technologies, however that is not completely true (Berg and Lindholm 2005, Puettmann et al. 2012, Gonzalez-Garcia et al. 2013). When the time aspect is not taken into account the results do not represent nor currently harvested roundwood, nor roundwood that will be produced in the future. The only possibility to analyse the environmental impacts for currently produced roundwood is by interdisciplinary approach that involves analysis of forest management history followed by LCA study. By using the approach in our previous research, the

* Corresponding author: E-mail: edgars.kuka@edi.lv 
Life cycle inventory for currently harvested birch roundwood

results showed that for currently produced pine roundwood most of the forest management practices that are used presently were not implemented or these activities involved non-mechanized equipment (Kuka et al. 2019). Therefore, roundwood that is currently produced and used for wood-based material production have different impact on the environment than it is for roundwood, which is assumed to be produced according to the current forest management practices. Such studies that take into account the time aspect for hardwood species have not yet been published moreover hardwood species as whole have not yet been analysed by the LCA methodologies in the Baltic State region (Klein et al. 2015).

Practically no forest in Latvia is completely natural and unmanaged. Already in the middle of $19^{\text {th }}$ century, forests were affected by human activities and only in particularly remote places some virgin forests were preserved (Susko 1997). Birch (Betula spp.) is the most dominant hardwood specie in Latvia taking around $30 \%$ of the total forest area (Ministry of Agriculture of the Republic of Latvia 2018). Moreover, it is the most commercially important hardwood species in the Northern and Eastern Europe (Hynynen 2010). In the Soviet times, the importance of birch was only minor and the species was even considered as weed. Nowadays the notion have changed and because of the research and development in the field, the importance of birch have reached new heights. In 2015, birch was the most regenerated wood specie in Latvia. By being a pioneer species with prolific seeds and fast juvenile growth, birch mainly regenerated naturally ( $88 \%$ by area) and often on former agricultural lands (Krastins 2000, Ministry of Agriculture of the Republic of Latvia 2016). It points to a predictable increase in birch timber resources after several years. Birch trees are mainly used for plywood, pulp, paper, chemical and 'greener' energy production (Ministry of Agriculture of the Republic of Latvia 2016, European Commission 2017). To analyse the environmental performance of these products the background information about the environmental burdens of raw wood products harvested from birch forests is vital. Therefore, the main objective of the present study was to determine which forest management processes should be included in the LCI for currently harvested birch roundwood in Latvia and based on these results compile the required data for the LCI.

\section{METHODS}

Life cycle inventory (LCI) study is carried out in compliance with the ISO 14040 and ISO 14044 standards. The standards provide overall guidelines for conducting LCI and life cycle assessment (LCA) studies.

\subsection{GOAL OF THE LCI STUDY}

The goal of the study is to carry out a cradle-to-gate LCI for currently produced birch (Betula spp.) roundwood in Latvia. The information will be useful as a background data for wood-based material manufacturers who uses birch roundwood as raw material. The data will also be used in further study in which LCA for double treated (thermal modification and impregnation with biocide) wood will be conducted. LCI will give all the necessary information (input and output data) for all the processes that should be considered based on the forest management history analysis. The present study is a part of the project aimed at improving wood bio-durability by combining thermal modification and impregnation with biocide.

\subsection{PRODUCT SYSTEM}

According to the legal acts of the Republic of Latvia, the final felling of birch trees is permitted when the age of trees reaches 51-71 years depending on the site index (Saeima of the Republic of Latvia 2000). Hence, birch trees that have reached the final felling age and are currently harvested started their life cycle in 1950s. At that time most of the forest managing operations that are in practice nowadays were not used or they involved non-mechanised equipment which can be excluded from the LCI system boundary because of the marginal impact on the environment. Production of birch roundwood (current practice) includes four subsystems (see Figure 1): seed production, seedling production, silvicultural operations and logging operations. All subsystems should be included in the system boundary for currently planted trees because most of the processes are mechanised and/or involve usage of different chemicals (fertilizers, repellents etc.), however for currently harvested birch trees the situation should differ. Therefore, analyses of forest management history in Latvia was done by using the accessible information about birch trees starting from 1950s. Assumptions were made based on the current forest management practices that each of the subsystem was done at specific time period: seed production and seedling production from 1950 till 1970; silvicultural operations from 1950 till 1980 and logging operations from 1970 till the present.

\subsection{FUNCTIONAL UNIT}

The functional unit (FU) for the present study was selected as $1 \mathrm{~m}^{3}$ of roundwood over bark. Bark is included in the FU because at this stage the bark is not removed from the roundwood and will or will not be removed depending 
on the further uses. Gonzalez-Garcia et al (2013) had similar approach regarding the FU in their research. As the reference unit 1 ha of forest land was used. Afterwards, the collected inventory data was recalculated to $1 \mathrm{~m}^{3}$ of roundwood over bark by using the data about the total terrestrial biomass. The total underground biomass (stump and roots) was not included in the system boundary because all of it is left on the forest site.

\subsection{SYSTEM BOUNDARY}

The system boundary of the LCI study was set by analysing the literature about forest management history in Latvia as described in the paragraph about product system. This was one of the main objectives of the present research and therefore will be discussed in the results section of this paper. All of the forest processes were considered from seed production to loading of the produced roundwood into hauling trucks at the forest roadside.

\subsection{ALLOCATION PROCEDURES}

More than one product is produced in thinning and logging operations, therefore allocation by volume was used. The extracted products are roundwood, pulpwood and fuelwood. Roundwood in the present study is the main product, and pulpwood and fuelwood are co-products. Also in the process forest waste is produced, however it is left on the forest ground and not analysed as co-product, but as biogenic $\mathrm{CO}_{2}$ emissions to air. Allocation by volume (mass) was used to allow better comparison between different studies as suggested by Klein et al (2015).

\subsection{DATA REQUIREMENTS}

The main data requirements for the present study were as follows:

- Geography coverage - the data primarily are collected, calculated or assumed by using sources that describe the situation in Latvia. If necessary, other sources are used for data that are not as dependent on location and that are not available for the studied location.

- Time and technology coverage - the data as much as possible represent the specific time period at which the relevant process was done. If such data were not available for the specific process assumptions were made based on the current forest management practices. data.

Precision, completeness, representativeness, consistency and reproducibility is considered when collecting the

\subsection{ASSUMPTIONS}

All assumptions in the present study are indicated and described when they are used. Nevertheless, if more appropriate alternatives are available assumptions are avoided as much as possible.

\section{RESULTS}

The forest management history was analysed by using several sources that describe the forest management practises in Latvia at the specific time period. Four main subsystems were analysed: seed production, seedling production, silvicultural operations and logging operations. Afterwards by considering the established system boundary the relevant data for the LCI was compiled and calculated.

\subsection{DETERMINATION OF SYSTEM BOUNDARY}

For seed production and seedling production the assumed time period is from 1950 till 1970. At the beginning of the $20^{\text {th }}$ century, birch forests took only $9.8 \%$ of the total forest area and with time the amount increased reaching 15 $\%$ in 1935 . At that time and long after that most of the birch forests regenerated naturally and most often by replacing other tree species. Birch as a pioneer specie with more prolific seeds and more rapid juvenile growth outgrew softwood species (mainly spruce) in clear-cutted areas and young forest stands (Buss and Vanags 1987, Strods and Zunde 1999). Artificial regeneration was more frequently used for softwood species and until 1970s the process involved mainly non-mechanised equipment (Mangalis 1989, Salins 1999, Baumanis et al. 2014). The analysis suggest that the seed production and seedling production subsystems should not be included in the system boundary because birch forests mostly regenerated naturally and the part that regenerated artificially did not include the use of mechanised equipment.

For silvicultural operations the assumed time period is from 1950 till 1980. The processes included in the subsystem are the most labour-intensive and difficult to mechanise. The importance of the silvicultural operations increased steadily with time and the processes mainly involved the use of non-mechanised equipment (Mangalis 
1989). The first mechanized equipment and machinery used in forest management activities were introduced in 1949. However, these devices were used only in logging operations. The first mechanized equipment (brush cutter) which was suitable for silvicultural operation was introduced in 1976, however at the beginning it was only tested in commercial thinnings (Buss and Vanags 1987, Salins 1999). Based on these facts the silvicultural operations can also be excluded from the system boundary because of the minor potential influence on the environment.

For logging operations the assumed time period is from 1970 till the present. The subsystem includes the following activities: commercial thinning, final cutting and loading in hauling trucks. Commercial thinning for birch forests is performed twice (at forest age 20 and 40) in a single forest rotation. The assumed time periods when these commercial thinnings were carried out are presented in Table 1. The beginning of forest thinning operations started in the late 1930 s, because previously it was thought that pruning is negatively affected by thinning processes. The first mechanised equipment and machinery (chainsaw and farm tractor) in logging operations was introduced in 1949, however these devices were used only in final cutting. Almost ten years later in 1957 chainsaws and farm tractors were also introduced in commercial thinnings. In time more efficient forwarders replaced the farm tractors in final cuttings and later also in commercial thinnings. In 1994 forwarders were the most frequently used machinery for forwarding in commercial thinnings. Harvesters for thinning purposes were not used until 2005 due to restrictions in regulations of Republic of Latvia Cabinet of Ministers No. 217 (Buss and Vanags 1987, Salins 1999, Petersons 2010). In 2010 around $50 \%$ of all commercial thinnings were done by harvesters (Petersons et al. 2010). Final cutting and loading are done currently and they involve the use of harvesters, forwarders and loading cranes. Overall situation about the use of equipment and machinery in logging operations is summarised in Table 1. These results were calculated based on the forest management history analysis and are used in further calculations regarding LCI.

Table 1: The use of equipment and machinery in logging operations for currently produced birch roundwood

\begin{tabular}{c|c|c|c|c|c|c|c}
\multirow{2}{*}{ Logging operations } & \multirow{2}{*}{ Time period } & \multicolumn{3}{|c|}{ Harvesting } & \multicolumn{3}{c}{ Forwarding } \\
\cline { 3 - 8 } & & $\begin{array}{c}\text { Non-mechanized } \\
\text { equipment, \% }\end{array}$ & $\begin{array}{c}\text { Chainsaw, } \\
\%\end{array}$ & $\begin{array}{c}\text { Harvester, } \\
\%\end{array}$ & $\begin{array}{c}\text { Non-mechanized } \\
\text { equipment, \% }\end{array}$ & $\begin{array}{c}\text { Farm } \\
\text { tractor, \% }\end{array}$ & $\begin{array}{c}\text { Forwarder, } \\
\%\end{array}$ \\
\hline First thinning & $1970-1990$ & 0 & 100 & 0 & 0 & 100 & 0 \\
Second thinning & $1990-2010$ & 0 & 87.5 & 12.5 & 0 & 15 & 85 \\
Final cutting & present & 0 & 0 & 100 & 0 & 0 & 100
\end{tabular}

From the forest management history analysis it can be concluded that only logging operations should be included in the system boundary for currently produced birch roundwood. The main differences between system boundaries for currently harvested and currently planted trees are shown in Figure 1. In addition, from personal communication with representative from JSC 'Latvia's State Forests' (2018) it was established that fertilizers are not used in Latvian forests. Fertilizers are only used in seedling production. 


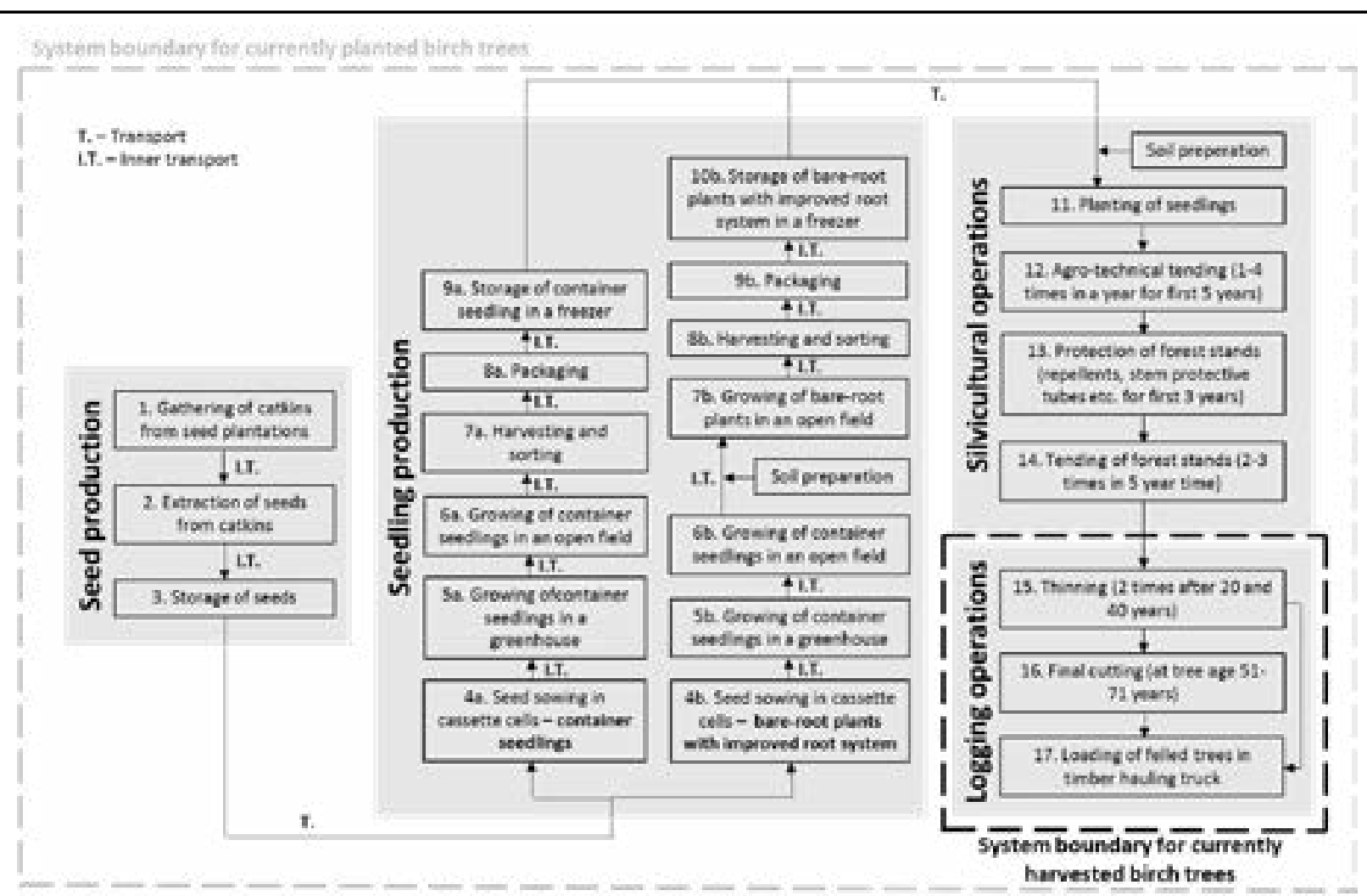

Figure 1: Subsystems included in the process chain of birch roundwood production in Latvia: system boundary for currently planted (grey dashed line) and for currently harvested (black dashed line) birch trees

\subsection{INVENTORY ANALYSIS}

As previously concluded only part of the processes should be considered when compiling LCI for currently produced birch roundwood in Latvia. For simplicity sake, processes that should be considered are included in the system boundary and the rest are excluded including processes with minor impact on the environment that involve the use of non-mechanized equipment, which technically should be included. All of the foreground unit processes that based on the system boundary are considered in the LCI are presented in Figure 2. The figure also shows the volume flow of timber which was calculated based on the LCI results. Solar energy inputs, all the ancillary inputs (equipment, machinery, land use, fuel, lubricating oil and transportation) and the emissions related to them are not presented in Figure 2, but are compiled in Table 4, where the input and output flows of each unit process are calculated according to $1 \mathrm{~m}^{3}$ of the specific intermediate product. 


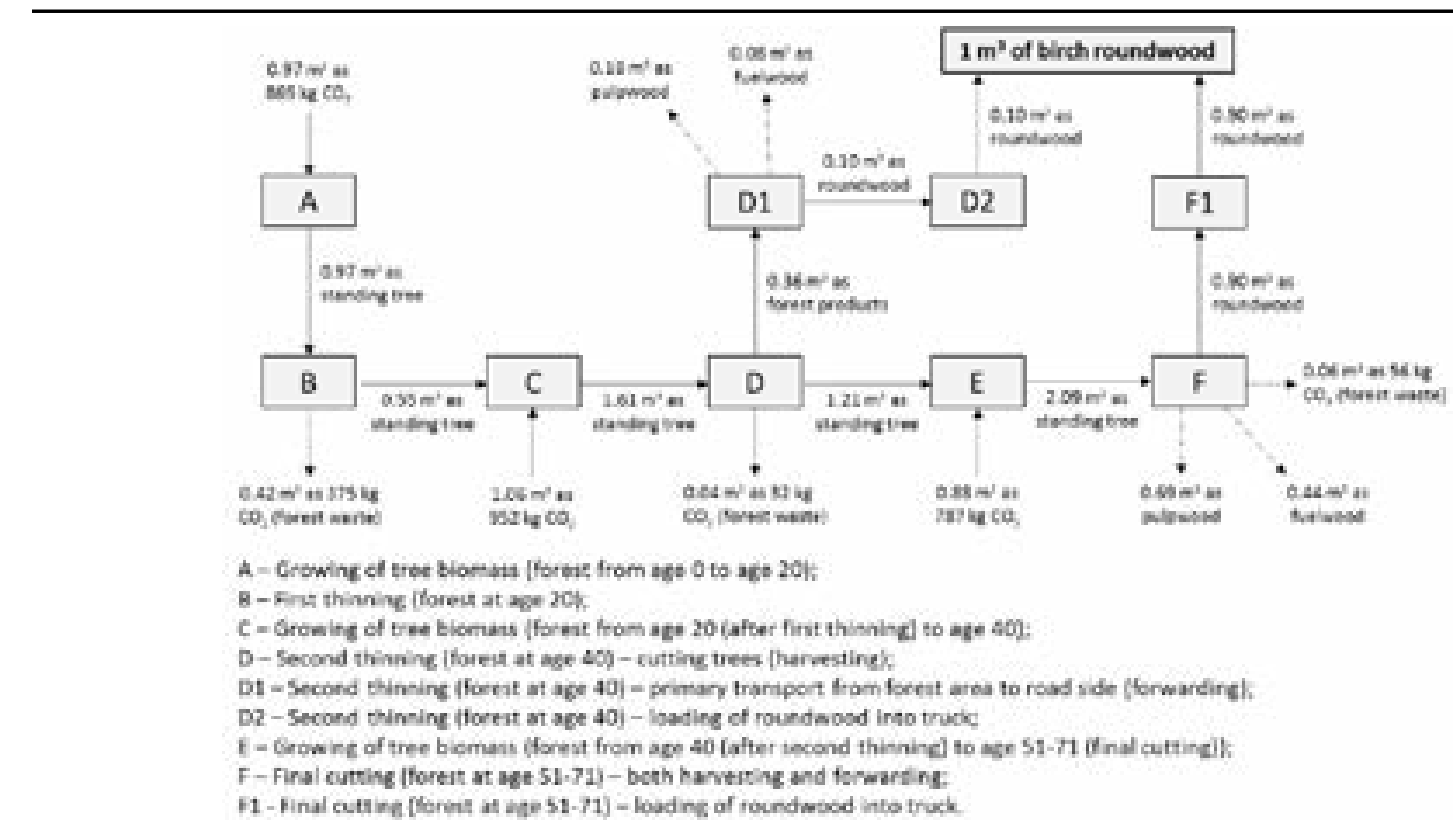

Figure 2: Volume flow of timber and foreground unit processes that are included in the system boundary for currently produced birch roundwood

The volume flow presented in Figure 2 is calculated and compiled based on the growth and thinning models for birch forests and the data about yield, removed biomass, amount of specific raw wood products and forest waste. The raw data are gathered from research papers, statistical information and from forest experts through surveys and personal communication. Most of the data were available in form of 1 ha of forest land (reference unit) and therefore the values afterwards were recalculated to comply with the functional unit $\left(1 \mathrm{~m}^{3} \mathrm{of}\right.$ birch roundwood). The amount of captured $\mathrm{CO}_{2}$ is calculated by taking into account that the specific density of birch is $470 \mathrm{~kg} / \mathrm{m}^{3}$ and the carbon content is $52 \mathrm{wt}$. \% of the dry wood biomass (Lazdins, 2015). Based on the growth models and statistical inventory of Latvian forest resources the total terrestrial biomass before the first commercial thinning is estimated around $137 \pm 7 \mathrm{~m}^{3} / \mathrm{ha}$ and the removed biomass during thinning is around $59 \pm 12 \mathrm{~m} /$ ha (Grinvalds et al. 2008, Jansons 2017). The removed biomass is classified as forest waste that is left on the forest ground as stated by forest experts (JSC 'Latvia's State Forests' 2018). Carbon in the forest waste was assumed to be released as $\mathrm{CO}_{2}$ in the result of aerobic decomposition (Giunolia et al. 2016). The total terrestrial biomass before second thinning is estimated around $231 \pm 12 \mathrm{~m}^{3} / \mathrm{ha}$ and the removed biomass is around $58 \pm 11 \mathrm{~m}^{3} /$ ha (Grinvalds et al. 2008, Jansons 2017). During second thinning only $9 \%$ of all removed biomass is classified as forest waste and the rest is forest products that include roundwood, pulpwood and fuelwood (Lazdans et al. 2004). The share of each type of wood biomass formed during second thinning is presented in Table 2 (JSC 'Latvia's State Forests' 2018). At the point when the birch forest reaches the final cutting age (forest at age 51-71) the total average terrestrial biomass is around $298 \pm 16 \mathrm{~m}^{3} / \mathrm{ha}$ (Jansons 2017). For the final cutting it is assumed that it is a clear cut and $0 \mathrm{~m}^{3} / \mathrm{ha}$ of standing terrestrial biomass is left on the forest ground. From the removed biomass $3 \%$ is classified as forest waste and the rest is forest products. The share of each type of wood biomass formed during final cutting is presented in Table 2 (Eurostat 2018). In total $142.6 \mathrm{~m}^{3} / \mathrm{ha}$ of roundwood is produced in one forest rotation. From that amount $10.2 \%$ is produced during second thinning and $89.8 \%$ during final cutting.

Table 2: Share of forest waste and products formed during thinnings and final cutting

\begin{tabular}{|c|c|c|c|c|}
\hline SHARE OF FOREST WASTE AND PRODUCTS, \% & Forest waste & Fuelwood & Pulpwood & Roundwood \\
\hline First commercial thinning (removed wood biomass: $59 \mathrm{~m}^{3} / \mathrm{ha}$ ) & 100 & 0 & 0 & 0 \\
\hline Second commercial thinning (removed wood biomass: $58 \mathrm{~m}^{3} / \mathrm{ha}$ ) & 9 & 21 & 45 & 25 \\
\hline Final cutting (removed wood biomass: $298 \mathrm{~m}^{3} / \mathrm{ha}$ ) & 3 & 21 & 33 & 43 \\
\hline
\end{tabular}

More detailed information regarding inputs and outputs for each unit process is presented in Table 4 . The raw data are gathered in variety of forms and recalculated accordingly to comply with $1 \mathrm{~m}^{3}$ of the specific unit process intermediate product. Such approach is used to give a possibility to use each of the unit process separately in other studies if necessary. The solar energy was calculated by using the lower calorific value of birch wood biomass 18.9 $\mathrm{MJ} / \mathrm{kg}$ and by assuming that the specific density is $470 \mathrm{~kg} / \mathrm{m}^{3}$ (Dolacis et al. 2003, Lazdins 2015). The data required for characterization of used equipment and machinery are gathered by taking into account the results presented in 
Table 1. It is assumed that the average fuel and lubricant consumption is not highly dependent on the tree diameter at breast height or the technology age. However, productivity and emissions are highly dependent on these previously mentioned factors, therefore these parameters significantly differ regarding commercial thinnings and final cutting. The data about productivity, fuel and lubricant consumption are presented in Table 3 (Kalejs et al. 2017, JSC 'Latvia's State Forests' 2018).

Table 3: Productivity, fuel and lubricant consumption of mechanical equipment and machinery during thinnings and final cutting

\begin{tabular}{l|c|c|c|c|c}
\multicolumn{1}{c|}{ PRODUCTIVITY, $\mathbf{~ m}^{\mathbf{3}} / \mathbf{h}$} & Chainsaw & Harvester & Farm tractor & Forwarder & Loader-crane \\
\hline First commercial thinning & 0.75 & - & - & - & - \\
Second commercial thinning & 1.13 & 14.0 & 4.0 & 9.5 & 19.0 \\
Final cutting & - & 20.4 & - & 12.9 & 19.0 \\
\hline \multicolumn{1}{c|}{ FUEL CONSUMPTION, L/h } & 0.40 & 12 & 6 & 12 & 17 \\
\hline LUBRICANT CONSUMPTION, L/h & 0.08 & 0.84 & 0.18 & 0.36 & 0.025
\end{tabular}

The emissions from burning of fuel are calculated according to Tier 2 technology-dependent approach which is described in EMEP/EEA air pollutant emission inventory guidebook 2016 (Winther 2016). The approach is chosen because of the high importance of technology age in the present study. The technology age of specific equipment and machinery used in thinnings and final cutting is presented in Table 1. For calculation purposes the density of gasoline, diesel and lubricant was assumed to be $750 \mathrm{~kg} / \mathrm{m}^{3}, 830 \mathrm{~kg} / \mathrm{m}^{3}$ and $850 \mathrm{~kg} / \mathrm{m}^{3}$, respectively. The amount of sulphur and lead in fuel is taken from the relevant literature and by considering the time aspect (Blumberg et al. 2003, Needleman and Gee 2013, Sorusbay 2014, Transport policy 2018). The data are required for calculations of $\mathrm{SO}_{2}$ and $\mathrm{Pb}$ emissions to air from burning of fuel. Lubricant is assumed to be partially burned in the process releasing $\mathrm{CO}_{2}$ emissions to air and the rest of the amount is assumed to be emitted to soil. The $\mathrm{CO}_{2}$ amount from lubricant is estimated according to Tier 1 for lubricants which is described in 2006 IPCC Guidelines for National Greenhouse Gas Inventories (Olivier et al. 2008). The data about the transportation distance and weight of the machinery are gathered from forest experts (JSC 'Latvia's State Forests' 2018). Background data for transportation, land use, chainsaw, machinery, gasoline, diesel, and lubricant production are taken from ecoinvent 3 database.

Table 4: Life cycle inventory for currently produced birch roundwood presented as foreground unit process data sets calculated to $1 \mathrm{~m}^{3}$ of specific intermediate product

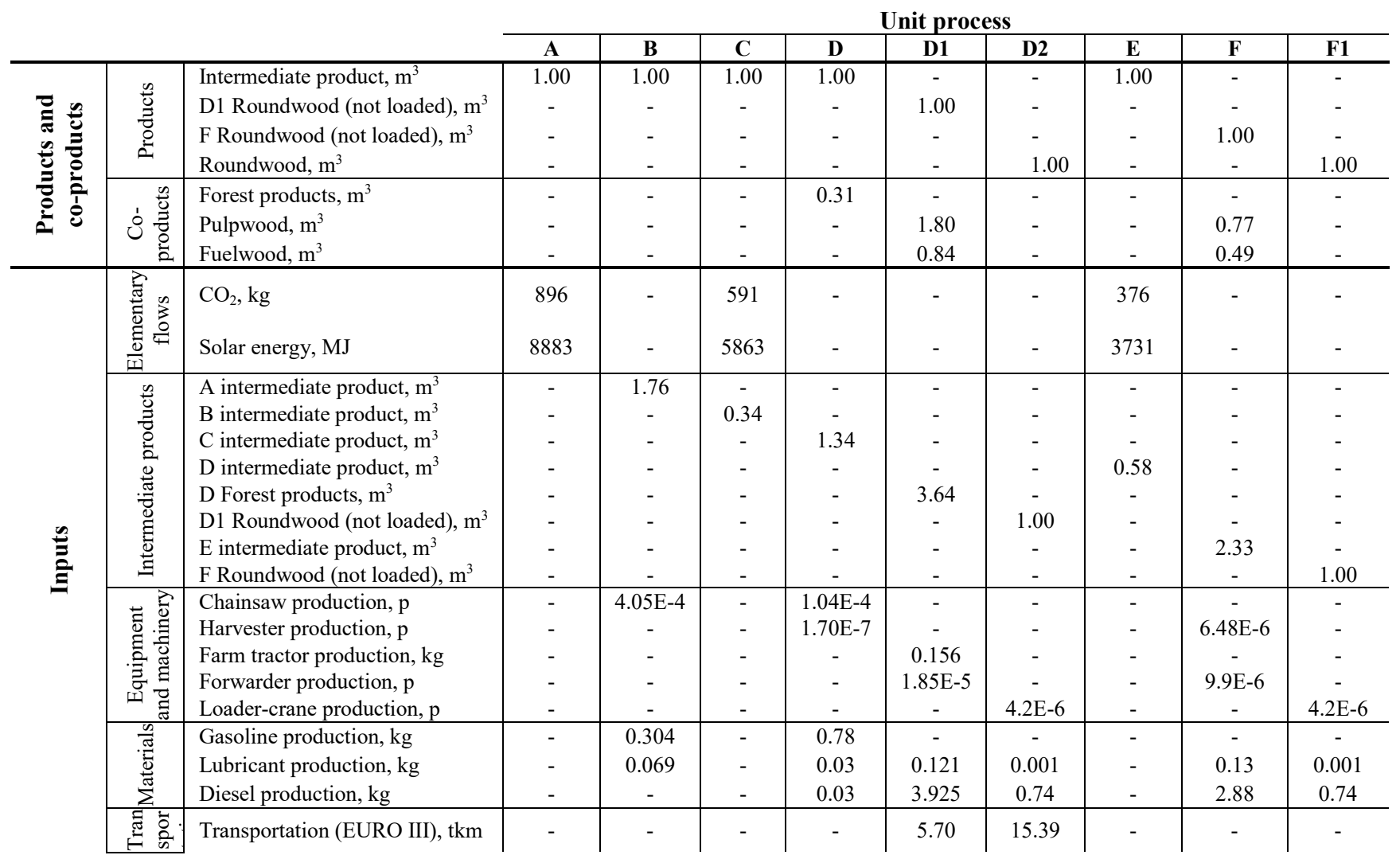


Life cycle inventory for currently harvested birch roundwood

\begin{tabular}{|c|c|c|c|c|c|c|c|c|c|c|c|}
\hline & & $\begin{array}{l}\text { Transportation (EURO IV), tkm } \\
\text { Transportation (EURO V), tkm }\end{array}$ & - & - & - & $\begin{array}{c}0.05 \\
-\end{array}$ & - & - & - & $\begin{array}{c}- \\
1.79\end{array}$ & $\begin{array}{c}- \\
15.38\end{array}$ \\
\hline & 苟 & $\begin{array}{l}\text { Transformation, from forest, } \mathrm{m}^{2} \\
\text { Transformation, to forest, } \mathrm{m}^{2} \\
\text { Occupation, forest, } \mathrm{m}^{2} \mathrm{a}\end{array}$ & $\begin{array}{c}73 \\
73 \\
1460 \\
\end{array}$ & $\begin{array}{l}- \\
- \\
-\end{array}$ & $\begin{array}{c}- \\
- \\
866 \\
\end{array}$ & $\begin{array}{l}- \\
- \\
-\end{array}$ & $\begin{array}{l}- \\
- \\
-\end{array}$ & $\begin{array}{l}- \\
- \\
-\end{array}$ & $\begin{array}{c}- \\
- \\
671\end{array}$ & $\begin{array}{l}- \\
- \\
-\end{array}$ & $\begin{array}{l}- \\
- \\
-\end{array}$ \\
\hline \multirow[t]{2}{*}{ 气气 } & $\begin{array}{l}\text { 志 } \\
0 \\
0\end{array}$ & $\begin{array}{l}\mathrm{CO}_{2} \text { (biogenic), kg } \\
\mathrm{BC}, \mathrm{g} \\
\mathrm{CH}_{4}, \mathrm{~g} \\
\mathrm{CO}, \mathrm{g} \\
\mathrm{CO}_{2}, \mathrm{~kg} \\
\mathrm{~N}_{2} \mathrm{O}, \mathrm{g} \\
\mathrm{NH}_{3}, \mathrm{~g} \\
\mathrm{NMVOC} \mathrm{g} \\
\mathrm{NO}_{x}, \mathrm{~g} \\
\mathrm{PM}_{10}, \mathrm{~g} \\
\mathrm{PM}_{2.5}, \mathrm{~g} \\
\mathrm{TSP} \mathrm{g} \\
\mathrm{SO}, \mathrm{g} \\
\mathrm{Lead}, \mathrm{g} \\
\mathrm{Cadmium}, \mathrm{mg} \\
\mathrm{Copper}, \mathrm{mg} \\
\text { Chromium, mg } \\
\text { Nickel, mg } \\
\text { Selenium, mg } \\
\text { Zinc, mg } \\
\text { Benz(a)anthracene, } \mu \mathrm{g} \\
\text { Benzo(b)fluoranthene, } \mu \mathrm{g} \\
\text { Dibenzo(a,h)anthracene, } \mu \mathrm{g} \\
\text { Benzo(a)pyrene, } \mu \mathrm{g} \\
\text { Chrysene, } \mu \mathrm{g} \\
\text { Fluoranthene, } \mu \mathrm{g} \\
\text { Phenanthene, } \mu \mathrm{g} \\
\end{array}$ & $\begin{array}{l}- \\
- \\
- \\
- \\
- \\
- \\
- \\
- \\
- \\
- \\
- \\
- \\
- \\
- \\
- \\
- \\
- \\
- \\
- \\
- \\
- \\
- \\
- \\
- \\
- \\
- \\
- \\
\end{array}$ & $\begin{array}{l}681.1 \\
0.073 \\
5.916 \\
212.6 \\
1.018 \\
0.005 \\
0.001 \\
78.60 \\
0.511 \\
1.455 \\
1.455 \\
1.455 \\
1.216 \\
0.122 \\
0.003 \\
0.517 \\
0.015 \\
0.021 \\
0.003 \\
0.304 \\
22.80 \\
12.16 \\
3.040 \\
12.16 \\
45.60 \\
136.8 \\
364.8 \\
\end{array}$ & $\begin{array}{l} \\
- \\
- \\
- \\
- \\
- \\
- \\
- \\
- \\
- \\
- \\
- \\
- \\
- \\
- \\
- \\
- \\
- \\
- \\
- \\
- \\
- \\
- \\
- \\
- \\
- \\
- \\
\end{array}$ & $\begin{array}{l}26.88 \\
0.028 \\
1.347 \\
48.55 \\
0.356 \\
0.005 \\
0.000 \\
17.92 \\
0.527 \\
0.318 \\
0.318 \\
0.318 \\
0.103 \\
0.012 \\
0.001 \\
0.183 \\
0.005 \\
0.008 \\
0.001 \\
0.108 \\
8.226 \\
4.606 \\
1.077 \\
4.010 \\
17.65 \\
48.46 \\
168.0 \\
\end{array}$ & $\begin{array}{c}- \\
2.215 \\
0.176 \\
28.98 \\
12.48 \\
0.544 \\
0.031 \\
7.104 \\
75.66 \\
3.308 \\
3.308 \\
3.308 \\
11.10 \\
- \\
0.039 \\
6.673 \\
0.196 \\
0.275 \\
0.039 \\
3.925 \\
314.0 \\
196.3 \\
39.25 \\
117.8 \\
785.0 \\
1766 \\
9813 \\
\end{array}$ & $\begin{array}{c}- \\
0.339 \\
0.022 \\
4.411 \\
2.347 \\
0.103 \\
0.006 \\
0.861 \\
15.29 \\
0.442 \\
0.442 \\
0.442 \\
1.789 \\
- \\
0.007 \\
1.262 \\
0.037 \\
0.052 \\
0.007 \\
0.743 \\
59.41 \\
37.13 \\
7.426 \\
22.28 \\
148.5 \\
334.2 \\
1857 \\
\end{array}$ & $\begin{array}{l}- \\
- \\
- \\
- \\
- \\
- \\
- \\
- \\
- \\
- \\
- \\
- \\
- \\
- \\
- \\
- \\
- \\
- \\
- \\
- \\
- \\
- \\
- \\
- \\
- \\
- \\
-\end{array}$ & $\begin{array}{r}62.73 \\
0.213 \\
0.037 \\
17.11 \\
9.182 \\
0.400 \\
0.023 \\
1.482 \\
4.563 \\
0.285 \\
0.285 \\
0.285 \\
0.069 \\
- \\
0.029 \\
4.891 \\
0.144 \\
0.201 \\
0.029 \\
2.877 \\
230.2 \\
143.9 \\
28.77 \\
86.31 \\
575.4 \\
1295 \\
7193 \\
\end{array}$ & $\begin{array}{c}- \\
0.055 \\
0.010 \\
4.416 \\
2.347 \\
0.103 \\
0.006 \\
0.382 \\
1.178 \\
0.074 \\
0.074 \\
0.074 \\
0.018 \\
- \\
0.007 \\
1.262 \\
0.037 \\
0.052 \\
0.007 \\
0.743 \\
59.41 \\
37.13 \\
7.426 \\
22.28 \\
148.5 \\
334.2 \\
1857\end{array}$ \\
\hline & 윰 & Lubricant, kg & - & 0.06 & - & 0.02 & 0.10 & 0.001 & - & 0.108 & 0.001 \\
\hline
\end{tabular}

\section{Conclusions}

By analysing forest management history it was possible to characterize the actual production process for currently produced birch roundwood in Latvia. The present study suggests that only logging operations should be included in the system boundary. Seed production, seedling production and silvicultural operations should be excluded because some of these subsystems were not practised at all or the activities included in the subsystems were performed with non-mechanized equipment. Based on these conclusions life cycle inventory (LCI) for birch roundwood was developed. The collected data for the LCI represent the actual production process taking into account the time aspect. These results are valuable for further calculations of environmental impacts and can be used as background data for evaluating different wood products. The interdisciplinary approach that considers forest management practice and technology development in time can give a more accurate characterization of environmental performance for currently produced roundwood. The study also suggest that currently manufactured wood products have lower environmental impacts than it is presented in their environmental product declarations due to these time related aspects. However, the environmental impacts for the future wood products will increase.

\section{ACKNOWLEDGMENTS}

The authors gratefully acknowledge the financial support by the European Regional Development Fund project No. 1.1.1.1/16/A/133.

\section{REFERENCES}


Baumanis, I., A. Jansons, and U. Neimane. 2014. Pine. Priede. Selection, genetics and seed production in Latvia (in Latvian). Daugavpils University academic publisher 'Saule', Daugavpils. 325 pp.

Berg, S., and E. Lindholm. 2005. Energy use and environmental impacts of forest operations in Sweden. J. Clean. Prod. 13:33-42.

Blumberg, K.O., M. P. Walsh, and C. Pera. 2003. Low-sulfur gasoline \& diesel: The key to lower vehicle emissions. The International Council on Clean Transportation (ICCT). 66 pp.

Bosner, A., T. Porsinsky, and I. Stankic. 2012. Forestry and life cycle assessment. In: Global Perspectives on Sustainable Forest Management, InTech. pp. 139-160.

Buss, M., and J. Vanags. 1987. Latvian forests (in Latvian). Avots, Riga. 176 pp.

Cardellini, G., T. Valada, C. Cornillier, E. Vial, M. Dragoi, V. Goudiaby, V. Mues, B. Lasserre, A. Gruchala, P. K. Rorstad, M. Neumann, M. Svoboda, R. Sirgmets, O. P. Nasaro, F. Mohren, W. M. J. Achten, L. Vranken, and B. Muys. 2018. EFO-LCI: A new life cycle inventory database of forestry operations in Europe. Environ. Manage. 61(6):1031-1047.

Dias, A. C., and Arroja, L. 2012. Environmental Impacts of eucalypt and maritime pine wood production in Portugal. J. Clean. Prod. 37:368-376.

Dolacis, J., E. Tomsons, and J. Hrols. 2003. Fuelwood comparison with other kinds of fuel. Environment. Technology. Resources. $67-72$

European Commission. 2017. Silver birch. https://ec.europa.eu/jrc/en/research-topic/forestry/qr-tree-project/silver-birch. Accessed March 18, 2019.

Eurostat. 2018. Roundwood removals by type of wood and assortment (2010-2016). https://ec.europa.eu/eurostat/data/database. Accessed April 28, 2019.

Giuntolia, J., A. Agostiniad, S. Caserinib, E. Lugatoc, D. Baxtera, and L. Marelli. 2016. Climate change impacts of power generation from residual biomass. Biomass Bioenerg. 89:146-158.

Gonzalez-Garcia, D., I. Krowas, G. Becker, G. Feijoo, and M. T. Moreira. 2013. Cradle-to-gate life cycle inventory and environmental performance of Douglas-fir roundwood production in Germany. J. Clean. Prod. 54:244-252.

Grinvalds, A., E. Linde, J. Gercans, M. Neicinieks, L. Sica, I. Brauners, and M. Gaigals. 2008. Thinning handbook (in Latvian). JSC 'Latvia's State Forests'. $112 \mathrm{pp}$.

Hynynen, J., P. Niemisto, A. Vihera-Aarnio, A. Brunner, S. Hein, and P. Velling. 2010. Silviculture of birch (Betula pendula Roth and Betula pubescens Ehrh.) in northern Europe. Forestry 83(1):103-119.

Jansons, J. 2017. National forest monitoring (in Latvian). Latvian State Forest Research Institute 'Silava'. http://www.silava.lv/petijumi/nacionlais-mea-monitorings.aspx. Accessed April 28, 2019.

JSC 'Latvia's State Forests'. 2018. Surveys and Personal Communication with Forest Experts.

Kaleja, S., A. Ziemelis, A. Lazdins, and P. O. Johansson. 2017. Comparison of productivity of Kranman Bison 10000 forwarder in stands harvested with harvester and chainsaw. In: Proceedings of the 8th International Scientific Conference Rural Development 2017, November 23-24, 2017, Kaunas, Lithuania. pp. 319-323.

Klein, D., C. Wolf, C. Schulz, and G. Weber-Blaschke. 2015. 20 years of life cycle assessment (LCA) in the forestry sector: state of the art and a methodical proposal for the LCA of forest production. Int. J. Life Cycle Assess. 20:556-575.

Krastins, O. 2000. Century in Latvian forests (in Latvian). Latvijas Vestnesis. https://www.vestnesis.lv/ta/id/3633. Accessed April $28,2019$.

Kuka, E., D. Cirule, I. Andersone, Z. Miklasevics, and B. Andersons. 2019. Life cycle inventory for currently produced pine roundwood. J. Clean. Prod. 235:613-625.

Lazdans, V., E. Epalts, Z. Karins, V. Kaposts, J. Liepa, T. Blija, A. Abolina, S. Laivina, and D. Lazdina. 2004. Forest management technique and technology influence on soil characteristics (In Latvian). Latvian State Forest Research Institute 'Silava', Salaspils. 59 pp.

Lazdins, A. 2015. Impact of forestry activities on greenhouse gas emissions and $\mathrm{CO}_{2}$ capture (in Latvian). Latvian State Forest Research Institute 'Silava', Salaspils. 144 pp.

Mangalis, I. 1989. Forest cultures (in Latvian). Zvaigzne. Riga. 360 pp.

Ministry of Agriculture of the Republic of Latvia. 2016. Forest Sector in the 25 Years of Independence of Latvia. Association 'Zalas majas', Riga. 47 pp.

Ministry of Agriculture of the Republic of Latvia. 2018. Latvian Forest Sector in Facts \& Figures 2018. Association 'Zalas majas', Riga. $54 \mathrm{pp}$.

Needleman, H., and D. Gee. 2013. Lead in petrol 'makes the mind give way', in: Late lessons from early warnings: science, precaution, innovation. Part A-Lessons from health hazards. European Environment Agency, Copenhagen. pp. 46-75.

Olivier, J. G. J., D. Gaudioso, M. Gillenwater, C. Ha, L. Hockstad, T. Martinsen, M. Neelis, H. Park, and T. Simmons. 2008. Nonenergy products from fuels and solvent use. In: 2006 IPCC Guidelines for National Greenhouse Gas Inventories. Institute for Global Environmental Strategies (IGES). pp. 5.1-5.18. 
Petersons, J. 2010. Factors affecting harvester productivity in forest thinning in Latvia. In: Proceedings of the 16th International Scientific Conference Research for Rural Development, May 24-26, 2010, Jelgava, Latvia. pp. 183-187.

Petersons, J., A. Dreska, and A. Saveljevs. 2010. Evaluation of removable tree reach factors and remaining standing tree quality during with machinery mechanised commercial thinning (in Latvian). Mezzinatne, 22(55), 116-128.

Puettmann, M., E. Oneil, J. Wilson, and L. Johnson. 2012. Cradle to gate life cycle assessment of softwood plywood production from the Southeast. CORRIM, Technical Report, $35 \mathrm{pp}$.

Saeima of the Republic of Latvia. 2000. Law on Forests. Latvijas Vestnesis, 98/99 (2009/2010), 16.03.2000. https:/likumi.lv/ta/en/en/id/2825. Accessed April 28, 2019.

Salins, Z. 1999. Forest use in Latvia (in Latvian). LLU Department of Forest Use. Jelgava. 270 pp.

Sorusbay, C. 2014. Internal Combustion Engine Fuels. Istanbul Technical University. http://web.itu.edu.tr/ sorusbay/ICE/index_files/LN04.pdf. Accessed April 28, 2019.

Strods, H., and M. Zunde. 1999. History of Latvian Forests until 1940 (in Latvian). WWF, Riga. 363 pp.

Susko, U. 1997. Natural forests in Latvia. Study on forest history, biodiversity structures and dependent species (in Latvian). WWF Latvian Program Office, Riga. $180 \mathrm{pp}$.

Transport policy. 2018. EU: Fuels: diesel and gasoline. https://www.transportpolicy.net/standard/eu-fuels-diesel-and-gasoline/. Accessed April 28, 2019.

Winther, M. 2016. EMEP/EEA air pollutant emission inventory guidebook 2016 - Update May 2017. Non-road mobile sources and machinery. European Environment Agency. 82 pp. 